\title{
Treatment of GH-deficient children with two different GH doses: effect on final height and cost-benefit implications
}

\author{
Giorgio Radetti, Fabio Buzi ${ }^{1}$, Claudio Paganini, Alba Pilotta ${ }^{1}$ and Barbara Felappi ${ }^{1}$ \\ Department of Paediatrics, Regional Hospital of Bolzano, via L Boehler No. 5, 39100 Bolzano, Italy and ${ }^{1}$ Department of Paediatrics, \\ University of Brescia, Brescia, Italy
}

(Correspondence should be addressed to G Radetti; Email: giorgio.radetti@asbz.it)

\begin{abstract}
Objective: Treatment of GH-deficient (GHD) children with higher doses of recombinant human GH (rhGH) than conventional ones has been reported to result in higher growth velocity and increased final height. These findings, however, were observed by comparing large but heterogeneous groups of children. We wanted to verify whether the same results could be obtained in two groups of appropriately well-matched children with isolated GHD treated with high vs conventional doses of rhGH. Methods: Out of two cohorts of GHD children, cohort A (on a weekly rhGH dose of $0.3 \mathrm{mg} / \mathrm{kg}$ body weight) and cohort B (on a weekly rhGH dose of $0.15 \mathrm{mg} / \mathrm{kg}$ body weight), we selected two groups, each including 13 patients, who before treatment were matched for age, sex and height standard deviation score (SDS). They were followed up until final height.

Results: Final height SDS was significantly higher in group A $(-0.45 \pm 0.36$ (s.D.) vs $-1.07 \pm 0.7$; $P=0.008)$, as well as height gain SDS $(1.81 \pm 0.58$ vs $1.23 \pm 0.62 ; P=0.002)$. The difference between final height SDS and target height SDS was positive only in group A and significantly higher in group A than in group B $(0.33 \pm 0.51$ vs $-0.46 \pm 0.7 ; P=0.01)$. Glucose tolerance was always normal in the group treated with higher doses.

Conclusion: The final height of children treated with higher doses of rhGH is increased, also in relation to their genetic target. The economical burden of this choice of treatment, however, has to be taken into account when evaluating the results.
\end{abstract}

European Journal of Endocrinology 148 515-518

\section{Introduction}

The introduction of growth hormone (GH) therapy in the late 1950 s significantly modified the statural outcome of children affected by GH deficiency (GHD), and even more so following the introduction over a decade ago of recombinant human $\mathrm{GH}$ (rhGH), which allowed GHD patients to be treated with higher doses of GH with greater consistency (1).

Clinical studies have shown that early diagnosis and treatment, bone age (BA) retardation, height at diagnosis and at pubertal onset, severity of GHD and higher daily doses of $\mathrm{GH}$ all have a positive influence on adult stature $(2-6)$. It is, however, still a matter of debate whether treatment with higher $\mathrm{GH}$ doses $(0.3 \mathrm{mg} / \mathrm{kg}$ per week) should be preferred to the conventional $(0.15-0.20 \mathrm{mg} / \mathrm{kg}$ per week). Discordant results have been reported with the higher dosage $(6,7)$, mainly due to the fact that these multicentre studies dealt with different study populations (8). We could not find any reports in the literature comparing the effects of conventional vs high $\mathrm{GH}$ doses on the final height in two groups of well-matched children, with the same genetic potential. There are only some medium-term studies, which, however, reported discordant results $(9-11)$. We therefore thought that it would be of interest to study the final height of two groups of well-matched children affected by isolated GHD, treated with high or conventional rhGH doses.

\section{Subjects and methods}

Out of two cohorts of GHD children (cohort A: 85 patients treated at the Regional Hospital of Bolzano, with a weekly rhGH dose of $0.3 \mathrm{mg} / \mathrm{kg}$ body weight; cohort B: 73 patients treated at the Paediatric Unit, University of Brescia, with a weekly rhGH dose of $0.15 \mathrm{mg} / \mathrm{kg}$ body weight), we selected two groups (group A and group B respectively), each including 13 children, who, at the beginning of treatment, were matched for age, sex and height standard deviation score (SDS). Matching criteria (see Table 1) included: age difference not greater than 1 year and height SDS 
Table 1 Matching table. The progression number refers to the recruitment order for each pair of subjects.

\begin{tabular}{|c|c|c|c|c|c|}
\hline \multirow[b]{2}{*}{ Pair } & \multirow[b]{2}{*}{ Sex } & \multicolumn{2}{|c|}{ Age } & \multicolumn{2}{|c|}{ Height SDS } \\
\hline & & Group A & Group B & Group A & Group B \\
\hline 1 & $f$ & 11.3 & 10.6 & -2.75 & -2.20 \\
\hline 2 & $\mathrm{~m}$ & 13.3 & 12.5 & -2.40 & -2.00 \\
\hline 3 & $f$ & 11.8 & 10.9 & -2.40 & -1.89 \\
\hline 4 & $\mathrm{~m}$ & 13.8 & 14.1 & -2.23 & -2.10 \\
\hline 5 & $\mathrm{~m}$ & 13.9 & 13.8 & -3.23 & -3.10 \\
\hline 6 & $\mathrm{~m}$ & 13.1 & 13.9 & -1.57 & -2.40 \\
\hline 7 & $\mathrm{~m}$ & 11.8 & 12.1 & -2.61 & -2.14 \\
\hline 8 & $\mathrm{~m}$ & 9.7 & 9.3 & -1.64 & -2.10 \\
\hline 9 & $\mathrm{~m}$ & 8.6 & 8.6 & -1.81 & -1.59 \\
\hline 10 & $\mathrm{~m}$ & 14.3 & 14.8 & -2.46 & -1.99 \\
\hline 11 & $\mathrm{~m}$ & 10.8 & 9.9 & -2.21 & -2.27 \\
\hline 12 & $\mathrm{~m}$ & 8.9 & 8.7 & -2.54 & -1.65 \\
\hline 13 & $f$ & 9.8 & 9.8 & -1.59 & -2.47 \\
\hline
\end{tabular}

difference not greater than 1 . There was no difference in life style and eating habits between the two groups. They were followed-up until final height was reached, the latter being evaluated when BA was more than 17 years in boys and 15 years in girls and when no further height gain was observed for 6 months. Overall, treatment lasted $5.4 \pm 1.4$ years in group $\mathrm{A}$ and $5.1 \pm 1.2$ years in group $B$, and in each group the same rhGH dose per $\mathrm{kg}$ was maintained throughout the whole study. The diagnosis of GHD was based on the following criteria: height less than -2 SDS or $<10$ th percentile when corrected for parental target (according to J M Tanner's 'Parents-allowed-for charts') (12); height velocity $<25$ th percentile for chronological age when measured for more than 1 year; BA delay $>2$ years compared with chronological age; peak $\mathrm{GH}<10 \mu \mathrm{g} / \mathrm{l}$ in at least two consecutive conventional pharmacological tests (insulin tolerance test, arginine- or clonidine-stimulation test). In particular, none of the patients had any organic GHD, panhypopituitarism or multiple pituitary hormone deficiency, all being affected by idiopathic isolated GHD, as confirmed by full endocrine evaluation and either pituitary computerized tomography or nuclear magnetic resonance. Peak GH after pharmacological stimulation was similar in the two groups (group A, 4.9 $2.5 \mu \mathrm{g} / \mathrm{l}$; group B $5.4 \pm 2.7 \mu \mathrm{g} / \mathrm{l})$. At the beginning of the study all patients were pre-pubertal, and all progressed regularly through puberty during the study until complete pubertal maturation. All group A patients (higher $\mathrm{GH}$ dose) underwent once a year an oral glucose tolerance test (OGTT) in order to assess possible changes in glucose tolerance.

The following auxological variables were considered: height, expressed as SDS (13); BA, evaluated according to the Greulich \& Pyle atlas (14); target height (TH), calculated as sex-corrected mid-parental height expressed in SDS units; height gain calculated as final height SDS minus height SDS at the beginning of treatment; and finally the difference between final height SDS and TH SDS. Clinical characteristics at the beginning are shown in Table 2. In particular, there was no significant difference in mean BA and mean TH SDS between the two groups, indicating that they showed the same genetic potential.

The study protocol was approved by the local Ethical Committees and informed consent was obtained from the parents only for the children treated with high rhGH dosage.

\section{Statistical analysis}

Student's unpaired $t$-test was used to evaluate possible differences in the above mentioned variables between the two groups. $P<0.05$ was considered statistically significant. Values are reported as means \pm S.D.

\section{Results}

Final height was significantly higher in group A $(P=0.008) \quad$ (Table 3), as well as height gain $(P=0.002)$. The difference between final height and TH was positive only in group A and significantly higher in group A than in group $\mathrm{B}(P=0.01)$.

The OGTT was always normal in the group treated with higher doses.

\section{Discussion}

Our study clearly shows that the final height of GHD children treated with higher doses of rhGH is increased compared with those receiving conventional treatment. The children in the high-dose group grew taller not only in absolute terms, but also in accordance with their genetic potential. In fact only the high-dose group significantly surpassed TH. We observed

Table 2 Clinical characteristics of the patients at the beginning of treatment.

\begin{tabular}{lccccc}
\hline & $\begin{array}{c}\text { Age } \\
\text { (years) }\end{array}$ & $\begin{array}{c}\text { BA } \\
\text { (years) }\end{array}$ & $\begin{array}{c}\text { Sex } \\
(\mathrm{M} / \mathrm{F})\end{array}$ & $\begin{array}{c}\text { Height } \\
(\mathrm{SDS})\end{array}$ & $\begin{array}{c}\text { TH } \\
(\mathrm{SDS})\end{array}$ \\
\hline Group A & $11.6 \pm 1.9$ & $9.0 \pm 2.3$ & $10 / 3$ & $-2.26 \pm 0.49$ & $-0.74 \pm 0.50$ \\
Group B & $11.5 \pm 2.2$ & $8.8 \pm 2.3$ & $10 / 3$ & $-2.30 \pm 0.59$ & $-0.67 \pm 0.97$ \\
$P$ & NS & NS & - & NS & NS \\
\hline
\end{tabular}

Table 3 Clinical characteristics of the patients at final height.

\begin{tabular}{lcccc}
\hline & $\begin{array}{c}\text { Age } \\
\text { (years) }\end{array}$ & $\begin{array}{c}\text { FH } \\
(\text { SDS })\end{array}$ & $\begin{array}{c}\text { Height gain } \\
(\text { SDS })\end{array}$ & $\begin{array}{c}\text { FH-TH } \\
(\text { SDS })\end{array}$ \\
\hline Group A & $18.4 \pm 1.67$ & $-0.45 \pm 0.36$ & $1.81 \pm 0.58$ & $0.33 \pm 0.51$ \\
Group B & $17.2 \pm 1.2$ & $-1.07 \pm 0.70$ & $1.23 \pm 0.62$ & $-0.46 \pm 0.70$ \\
$P$ & - & 0.008 & 0.002 & 0.01 \\
\hline
\end{tabular}

$\mathrm{FH}$, final height. 
a difference in final height, corrected for the parental height, of 0.79 SDS, which roughly corresponds to $5.9 \mathrm{~cm}$.

Our results agree with those of other larger studies reporting a positive relationship between increasing $\mathrm{GH}$ doses and improvement in adult height $(2-6)$ and suggest that a $\mathrm{GH}$ dose of $0.3 \mathrm{mg} / \mathrm{kg}$ per week is more effective than that of $0.15 \mathrm{mg} / \mathrm{kg}$ per week. This is also in agreement with the findings of Blethen et al. (6), but not with those of August et al. (7). However, it has been suggested (3) that the better results obtained in The Genentech Growth Study Group study (6) were no longer apparent when the mid-parental height was taken into account. We can only comment that it is rather difficult to compare the results of two different regimens of GH obtained in two not wellmatched samples.

Overall, according to the literature $(2-6)$ and from our own findings, it seems that the more $\mathrm{GH}$ you give, the taller the child will be. Stanhope et al. (15) and MacGillivray et al. (16), however, were not able to improve the adult height of a group of GHD children by increasing the $\mathrm{GH}$ doses from $5 \mathrm{mg} / \mathrm{m}^{2}$ per week to $10 \mathrm{mg} / \mathrm{m}^{2}$ per week only at the beginning of puberty, suggesting that intensive treatment needs to be started during the prepubertal period in order to be effective, unless very high doses of $\mathrm{GH}(0.7 \mathrm{mg} / \mathrm{kg}$ per week) are employed during puberty, as proposed by Mauras et al. (17).

There are, however, some considerations to be made. First the cost of doubling the dose. We calculated that for one child, considering the mean difference of $5.9 \mathrm{~cm}$ and a mean period of 5 years of therapy, each centimetre ultimately costs 27368 Euro. If we consider the situation in Italy, where around 5500 children are currently being treated with the conventional GH dosage, the difference in cost between the two regimens, calculated with the same criteria, would amount to 150524000 Euro. Therefore this should seriously be taken into consideration before raising the dosage.

Some potential side-effects should also be taken into account. It is well known, in fact, that GH excess has a negative influence on glucose tolerance, and recently it has been reported that $\mathrm{GH}$ treatment of GHD children can advance the onset of diabetes mellitus, at least in an already predisposed population (18). We did not find, however, any signs of glucose intolerance in our patients. Moreover, the potential side-effects of highdose GH treatment on the cardiovascular system have not as yet been fully clarified (19). The theoretical risk of an increased incidence of adulthood cancer associated with an elevated serum insulin-like growth factor (IGF)-I level in a GH recipient, is, however, lowered by the fact that GH also increases the level of IGF-binding protein-3, which would inhibit IGF-I action (20). Other possible side-effects, such as benign intracranial hypertension, prepubertal gynaecomastia, arthralgia and oedema, are very rare in children (21), and were not seen in our study population. In conclusion, the use of rhGH, with its unlimited supply, allows a more intensive treatment of GHD children, leading to a better final outcome, although at a questionable cost.

\section{References}

1 Grumbach MM, Bin-Abbas BS \& Kaplan SL. The growth hormone cascade: progress and long-term results of growth hormone treatment in growth hormone deficiency. Hormone Research 199849 $41-57$.

2 Hintz RL. Final height of growth hormone-treated patients with growth hormone deficiency: the North American experience. Acta Paediatrica $1999 \mathbf{8 8} 70-71$.

3 Cutfield W, Lindberg A, Albertsson Wikland K, Chatelain P, Ranke MB \& Wilton P. Final height in idiopathic growth hormone deficiency: the KIGS experience. Acta Paediatrica 199988 72-75.

4 Severi F. Final height in children with growth hormone deficiency. Hormone Research $199543138-140$.

5 Cacciari E, Cicognani A, Pirazzoli P, Zucchini S, Salardi S, Balsamo A et al. Final height of patients treated for isolated $\mathrm{GH}$ deficiency: examination of 83 patients. European Journal of Endocrinology $199713753-60$.

6 Blethen SL, Baptista J, Kuntzle J, Foley T, LaFranchi S \& Johanson A. Adult height in growth hormone (GH)-deficient children treated with biosynthetic GH. The Genentech Growth Study Group. Journal of Clinical Endocrinology and Metabolism $1997 \mathbf{8 2}$ 418-420.

7 August GP, Julius JR \& Blethen SL. Adult height in children with growth hormone deficiency who are treated with biosynthetic growth hormone: the National Cooperative Growth Study experience. Pediatrics $1998 \mathbf{1 0 2} 512-516$.

8 Drake WM, Howell SJ, Monson JP \& Shalet SM. Optimizing GH therapy in adults and children. Endocrine Reviews 200122 425-450.

9 De Muinck Keizer-Schrama S, Rikken B, Hokken-Koelega A, Witt JM \& Drop S. The Dutch Growth Hormone Working Group. Comparative effect of two doses of growth hormone for growth hormone deficiency. Archives of Disease in Childhood $19947112-18$.

10 Radetti G, Buzi F, Paganini C, Martelli C \& Adami S. A four year dose-response study of recombinant human growth hormone treatment of growth hormone deficient children: effects on growth, bone growth and bone mineralization. European Journal of Endocrinology $200014242-46$.

11 Yokoya S, Araki K, Igarashi Y, Kohno H, Nishi Y, Hasegawa Y et al. High-dose growth hormone $(\mathrm{GH})$ treatment in prepubertal GH-deficient children. Acta Paediatrica 199988 76-79.

12 Tanner JM. Foetus into Man: Physical Growth from Conception to Maturity, edn 2. Ware: Castelmead Publications, 1989.

13 Tanner JM, Whitehouse RH \& Takaishi M. Standards from birth to maturity for height, weight, height velocity and weight velocity; British children 1965. Archives of Disease in Childhood $1966 \mathbf{4 1}$ 454-471 and 613-635.

14 Greulich WW \& Pyle SL. Radiographic Atlas of Skeletal Development of the Hand and Wrist, edn 2. Stanford, CA: Stanford University Press, 1969.

15 Stanhope R, Uruena M, Hindmarsh P, Leiper AD \& Brook CGD. Management of growth hormone deficiency through puberty. Acta Paediatrica Scandinavica 1991372 (Suppl) 47-52.

16 MacGillivray MH, Blethen SL, Buchlis JG, Clopper RR, Sandberg DE \& Conboy TA. Current dosing of growth hormone in children with growth hormone deficiency: how physiologic? Pediatrics 1998102 527-530.

17 Mauras N, Attie KM, Reiter EO, Saenger P \& Baptista J. High dose recombinant human growth hormone $(\mathrm{GH})$ treatment 
of GH-deficient patients in puberty increases near-final height: a randomized, multicenter trial. Genentech, Inc., Cooperative Study Group. Journal of Clinical Endocrinology and Metabolism $2000853653-3660$.

18 Cutfield WS, Wilton P, Bennmarker H, Albertsson Wikland K, Chatelain $\mathrm{P} \&$ Ranke MB. Incidence of diabetes mellitus and impaired glucose tolerance in children and adolescents receiving growth-hormone treatment. Lancet 2000355 610-613.

19 Radetti G, Crepaz R, Paganini C, Gentili L \& Pitscheider W. Medium-term cardiovascular effects of high-dose growth hormone treatment in growth hormone deficient children. Hormone Research 199952 247-252.
20 Cohen P, Clemmons DR \& Rosenfeld RG. Does the GH-IGF axis play a role in cancer pathogenesis? Growth Hormone Research $200010297-305$.

21 GH Research Society. Consensus guidelines for the diagnosis and treatment of growth hormone $(\mathrm{GH})$ deficiency in childhood and adolescence: summary statement of the GH Research Society. Journal of Clinical Endocrinology and Metabolism $2000 \mathbf{8 5}$ 3990-3993.

Received 26 August 2002

Accepted 20 February 2003 